\title{
KARAKTER TOKOH PROTAGONIS DALAM NOVEL HELLO SALMA KARYA ERISCA FEBRIANI DAN IMPLIKASINYA TERHADAP PEMBELAJARAN BAHASA INDONESIA
}

\author{
Fatimah $^{1)}$, Ratna Dewi Kartikasari ${ }^{2}$ \\ ${ }^{1)}$ Pendidikan Bahasa dan Sastra Indonesia, Fakultas Bahasa dan Seni, \\ Universitas Indraprasta PGRI \\ ${ }^{2)}$ Pendidikan Bahasa dan Sastra Indonesia, Fakultas Ilmu Pendidikan, \\ Universitas Muhammadiyah Jakarta \\ email: fatimahifat4@gmail.com
}

\begin{abstract}
ABSTRAK
Tujuan dari penelitian ini adalah untuk menganalisis karakter tokoh protagonis dalam novel Hello Salma karya Erisca Febriani. Penulis juga berharap pembaca lebih memahami lebih dalam mengenai karakter protagonis. Metode penelitian yang digunakan untuk menganalisis novel ini adalah metode deskriptif yang berarti dilakukan dengan cara mendeskripsikan fakta-fakta kemudian disusul dengan analisis. Hasil penelitian menggambarkan karakter protagonis yang dominan pada aspek pikiran dan diikuti oleh dua aspek lainnya, yaitu tindakan dan ujaran. Dari hasil analisis karakter tokoh protagonis dalam novel Hello Salma karya Erisca Febriani dan implikasinya terhadap pembelajaran bahasa Indonesia, penulis menyimpulkan bahwa aspek karakter tokoh protagonis dalam penelitian ini dominan pada aspek pikiran tokoh. Karakter protagonis memberikan nilai positif dalam menanam nilai-nilai kebaikan, dapat menjadi teladan dalam kehidupan, dan meningkatkan kemampuan apresiasi sastra
\end{abstract}

Kata Kunci: Karakter Tokoh Protagonis, Novel, Implikasi Terhadap Pembelajaran Bahasa Indonesia.

\section{PENDAHULUAN}

Novel merupakan karangan panjang berupa fiksi yang mengandung rangkaian cerita kehidupan manusia. Persoalan terhadap diri sendiri serta lingkungan yang terdapat banyak sistem nilai dan norma. Dalam hal ini pengarang berusaha mengarahkan pembaca untuk mengetahui pesan tersembunyi yang terkandung di dalam novel. Pembaca dapat mengambil pelajaran dan manfaat dibalik cerita atau masalah yang terdapat di dalam novel, sehingga pembaca dapat mencontoh hal baik dan meninggalkan hal buruk di dalam 
Website:https://jurnal.umj.ac.id/index.php/penaliterasiEmail:penaliterasi@umj.ac.id

kehidupan nyata. Oleh karena itu, cerita di dalam novel memiliki hubungan yang erat terhadap kehidupan manusia.

Pesan tersembunyi yang pengarang sampaikan kepada pembaca tidak selalu tersirat. Pengarang menyembunyikan pesan di dalam unsur intrinsik, seperti tema, alur, latar, amanat, penokohan, sudut pandang, dan gaya bahasa. Di antara ketujuh unsur tersebut, biasanya pesan tersampaikan melalui tokoh. Sifat, sikap, atau karakter tokoh, seperti hal baik ataupun buruk dapat menuntun pembaca pada pesan yang ingin disampaikan oleh pengarang.

Novel karya Erisca Febriani dengan judul Hello Salma adalah novel yang menarik dibahas. Di dalam novel ini memberikan pelajaran hidup untuk menerima kenyataan, berjuang, berkorban, serta pentingnya mengungkapkan perasaan. Pengarang berhasil memainkan perasaan pembaca dan berhasil menyampaikan pesan yang ingin disampaikan melalui tokoh dalam cerita. Daya tarik terhadap novel Hello Salma karya Erisca Febriani terletak pada karakter tokoh.

Karakter masing-masing tokoh yang menarik, terutama pada tokoh protagonis yang begitu hidup dan nyata, sehingga membuat pembaca ikut merasakan apa yang dirasakan tokoh protagonis di dalam novel. Alur cerita dalam novel ini benarbenar ringan, namun tetap menarik pembaca.

Cerita dalam novel ini tidak hanya kisah asmara yang disampaikan, tetapi ada banyak bagian menarik untuk dikaji karena menggambarkan karakter manusia untuk mencapai target hidup serta dalam mengatasi masalah. Dalam novel ini juga mengandung pesan moral dan nilai-nilai kehidupan sosial. Keistimewaan novel dapat dilihat dari isi cerita, baik dalam penyusunan plot, penokohan, dan konflik yang terdapat di dalamnya. Dalam hal ini penulis akan berfokus pada unsur penokohan.

Penokohan disebut juga unsur yang menampilkan tokoh atau pemeran dalam carita, sehingga dapat diketahui karakter atau sifat para tokoh. Dalam unsur penokohan mencangkup perwatakan tokoh dan cara pengarang menempatkan tokoh dalam cerita. Tokoh dibedakan menjadi beberapa jenis. Pembedaan tersebut didasarkan pada peran tokoh dalam cerita, seperti tokoh protagonis, antagonis, dan tritagonis. Dalam novel Hello Salma karya Erisca Febriani, penulis tertarik untuk mengkaji lebih jauh tokoh protagonis dalam novel tersebut.

Penulis mengaitkan paparan di atas dengan pembelajaran bahasa Indonesia di sekolah. Pembelajaran bahasa Indonesia, terutama sastra, di sekolah dari dulu selalu menjadi permasalahan. Hadirnya novel Hello Salma karya Erisca Febriani merupakan salah satu fenomena yang dapat meningkatkan pembelajaran bahasa Indonesia bagi para peserta didik. Isi cerita yang menarik dalam novel Hello Salma berhasil menjadi sorotan di kalangan peserta didik, terlebih lagi latar dan konflik dalam novel tersebut sangat dekat dengan dunia mereka. Novel ini dapat menjadi acuan bagi para peserta didik dalam menghadapi pilihan.

Melalui novel ini mereka juga dapat belajar membuka hati untuk lebih peka dan peduli pada keadaan sekitar. Dengan 
Fatimah $^{1)}$, Ratna Dewi Kartikasari ${ }^{2)}:$ Karakter Tokoh Protagonis dalam Novel Hello Salma Karya EriscaA Febriani dan Implikasinya terhadap Pembelajaran Bahasa Indonesia

Website:https://jurnal.umj.ac.id/index.php/penaliterasiEmail:penaliterasi@umj.ac.id

hadirnya karya sastra yang dicintai dapat memudahkan peserta didik dalam meningkatkan pembelajaran bahasa Indonesia.

\section{METODE PENELITIAN}

Penggunaan metode yang sesuai dengan permasalahan yang diteliti akan menghasilkan penelitian yang dapat dipertanggungjawabkan.

Metode adalah cara ilmiah untuk mendapatkan data dengan tujuan dan kegunaan tertentu. Dalam menganalisis novel Hello Salma karya Erisca Febriani, penulis menggunakan metode deskriptif. (Bahtiar dan Aswinarko, 2013) memaparkan bahwa metode deskriptif adalah metode yang dilakukan dengan cara mendeskripsikan fakta-fakta kemudian disusul dengan analisis. Konsep yang digunakan dalam penelitian ini adalah mengacu pada aspek karakter yang terdapat pada novel Hello Salma karya Erisca Febriani.

Metode pada penelitian ini bertujuan untuk mendapatkan deskripsi atau gambaran secara faktual dan akurat terhadap objek yang diteliti. Penelitian ini berbentuk pengumpulan data dan analisis data. Sumber analisis data dalam penelitian ini, yaitu karakter tokoh protagonis yang terdapat di dalam teks novel.

Teknik penelitian yang digunakan dalam penelitian ini adalah teknik analisis isi. (Bahtiar dan Aswinarko, 2013) mengungkapkan bahwa analisis isi berhubungan dengan isi komunikasi, baik secara verbal maupun nonverbal yang berkaitan dengan isi dan pesan komunikasi dalam kehidupan manusia. Pesan komunikasi yang dimaksud seperti masalah-masalah sosial, politik, ekonomi, dan lainnya. Akan tetapi, dalam karya sastra, isi yang dimaksudkan adalah pesanpesan yang terdapat di dalamnya. Dalam menggunakan teknik analisis isi, peneliti dibantu dengan adanya tabel. Tabel digunakan untuk menentukan banyaknya karakter tokoh yang telah diperoleh dari hasil membaca dan menganalisis isi dari teks novel. Di dalam tabel berisi hal-hal yang dapat mendukung dan memperkuat fakta mengenai tokoh protagonist. Isi dari tabel analisis isi, yaitu kutipan novel, jenis karakter, dan total atau jumlah data yang diperoleh.

Fokus dalam penelitian ini adalah karakter tokoh protagonis dalam novel Hello Salma karya Erisca Febriani dan implikasinya dalam pembelajaran bahasa Indonesia. Subfokus pada penelitian karakter tokoh protagonis pada novel Hello Salma karya Erisca Febriani ini terdiri tiga subfokus, yaitu tindakan, ujaran, dan pikiran.

Instrumen yang digunakan dalam penelitian ini adalah peneliti itu sendiri (Sugiono, 2017). Peneliti bertindak sebagai instrumen kunci atau alat dari penelitian. Dalam hal ini peneliti akan dibantu dengan tabel analisis data tentang karakter tokoh protagonis yang mencakup: tindakan, ujaran, dan pikiran.

\section{HASIL DAN PEMBAHASAN}

Berdasarkan data temuan penelitian, penulis akan menganalisis data tersebut satu persatu sesuai dengan karakter tokoh protagonis dalam novel Hello Salma karya 
Fatimah $^{1)}$, Ratna Dewi Kartikasari ${ }^{2)}:$ Karakter Tokoh Protagonis dalam Novel Hello Salma Karya EriscaA Febriani dan Implikasinya terhadap Pembelajaran Bahasa Indonesia

Website:https://jurnal.umj.ac.id/index.php/penaliterasiEmail:penaliterasi@umj.ac.id

Erisca Febriani. Kutipan yang ditemukan sebanyak 204 temuan. Penulis menemukan aspek pikiran sebanyak $39 \%$ atau setara dengan 80 temuan data, aspek tindakan sebanyak $26 \%$ atau setara dengan 52 temuan data, dan aspek ujaran sebanyak 35 $\%$ atau setara dengan 72 temuan data. Hal tersebut terdapat pada tabel persentase karakter tokoh protagonis, sebagai berikut.

Tabel 1.

Persentase Karakter Tokoh Protagonis pada Novel Hello Salma Karya Erisca Febriani.

Berdasarkan analisis yang telah diuraikan, karakter tokoh protagonis dalam novel Hello Salma karya Erisca Febriani yang memiliki tokoh protagonis, yaitu Salma dan Nathan. Salma adalah seorang perempuan yang memiliki karakter penurut, peduli sesama, dan menutup diri. Sementara Nathan memiliki karakter sebagai laki-laki yang peduli terhadap orang yang membutuhkan. Karakter tokoh protagonis yang paling dominan menghiasi novel ini adalah pikiran tokoh. Adapun penafsiran data atau adegan dalam novel tersebut diuraikan oleh penulis berdasarkan karakter tokoh protagonis sebagai berikut.

\section{Unsur Tindakan}

Menurut (Wardiah, 2016) tindakan merupakan berbagai kecenderungan untuk bertindak dari segi praktik. Sikap belum tentu terwujud dalam bentuk tindakan. Untuk mewujudkan sikap menjadi tindakan, diperlukan suatu kondisi

\begin{tabular}{|c|c|c|}
\hline $\begin{array}{c}\text { Karakter } \\
\text { Tokoh }\end{array}$ & Jumlah & Persentase \\
\hline Tindakan & 52 & $26 \%$ \\
\hline Ujaran & 72 & $35 \%$ \\
\hline Pikiran & 80 & $39 \%$ \\
\hline Total & 204 & $\mathbf{1 0 0 \%}$ \\
\hline
\end{tabular}

yang memungkinkan, seperti fasilitas dan sarana prasarana.

Temuan tindakan tokoh protagonis di dalam novel Hello Salma karya Erisca Febriani dapat digambarkan dalam kutipan di bawah ini.

a. Berbicara soal hobi, Salma suka sekali menulis sebuah cerita di blog. Selain itu, dia juga suka mengoleksi novel. Sejak SD, Salma menyisihkan uang jajannya untuk membeli novel. Kecintaannya pada buku mengalahkan apa pun. Bahkan, dia rela membawa bekal berbulan-bulan agar irit uang jajan. Untuk mendukung hobinya, sewaktu SMP, Salma masuk ke ekskul madding dan sering mengirim puisi hingga cerita pendek.

Sayangnya, memasuki SMA, ayahnya melarang Salma mengikuti ekskul Mading lantaran dinilai kurang bermanfaat. Karena tidak mau melawan keinginan orang tua, 
Fatimah ${ }^{1)}$, Ratna Dewi Kartikasari ${ }^{2)}$ : Karakter Tokoh Protagonis dalam Novel Hello Salma Karya EriscaA Febriani dan Implikasinya terhadap Pembelajaran Bahasa Indonesia

Website:https://jurnal.umj.ac.id/index.php/penaliterasiEmail:penaliterasi@umj.ac.id

akhirnya Salma menurut dan sebagai gantinya, dia melampiaskan hasratnya menulis dengan membuat sebuah blog yang menjadi pelariannya setelah lelah seharian belajar dari pagi sampai malam. (hlm. 52)

Analisis pada kutipan di atas menjelaskan tindakan Salma yang tidak ingin dianggap anak durhaka yang melawan orang tua. Salma diperintakan oleh ayahnya untuk keluar dari ekskul madding dan dia menuruti perintah itu. Namun, Salma melampiaskan rasa kesal dan lelahnya dengan cara menulis.

b. Dari sorot wajah Rebecca menunjukkan keterkejutan. "Gue Nathan, anak kelas 11IPS-2."

Tanpa basa-basi, Nathan mengambil pena di dekat Rebecca lalu menuliskan nomornya di buku Rebecca yang terbuka di atas meja. "Kalau lo mau cerita, lo bisa chat atau telepon gue..." (hlm. 62)

Kutipan di atas menjelaskan tentang tindakan Nathan yang memperkenalkan diri pada Rebecca dan menuliskan nomor ponselnya di buku Rebecca. Nathan berharap dengan memberikan nomornya pada Rebecca, dia akan menghubungi Nathan dan bercerita tentang masalahnya. Tindakan Nathan merupakan bentuk kepeduliannya terhadap Rebecca.

2. Unsur Ujaran
Kridalaksana, mengemukakan bahwa ujaran adalah kalimat atau bagian kalimat yang dilisankan. Dalam hal ini ujaran biasanya diapit oleh dua kesenyapan. Ujaran mengekspresikan makna dan tujuan dari pembicara. Temuan ujaran tokoh protagonis di dalam novel Hello Salma karya Erisca Febriani dapat digambarkan dalam kutipan di bawah ini.

a. "Kalau lo nggak suka sesuatu, lo ngomong. Jangan dipendam. Lo itu bukan pohon, Sal."

"Nggak semudah itu," Salma menggelengkan kepala, raut wajahnya berubah yang semula bahagia, terlihat muram. "Faktanya gue emang nggak bisa buat kedua orang tua gue bangga. Manusia paling nggak berguna, yang cuma jadi beban buat Papa sama Mama dan cuma bisa buat malu keluarga karena nggak berhasil masuk kedokteran." (hlm. 256)

Kutipan di atas menjelaskan tentang Nathan yang memberi nasihat pada Salma bahwa segala sesuatu yang tidak dia sukai harus diungkapkan. Dengan raut wajah muram, Salma menjawab bahwa dia merasa tidak berguna karena tidak bisa membuat orang tuanya bangga, membebani orang tuanya, dan membuat malu keluarga.

b. "Cantik tapi lebay, ilfeel ah. Dah, sini ponsel gue." Dengan paksa, Deni 
Fatimah ${ }^{1)}$, Ratna Dewi Kartikasari ${ }^{2)}$ : Karakter Tokoh Protagonis dalam Novel Hello Salma Karya EriscaA Febriani dan Implikasinya terhadap Pembelajaran Bahasa Indonesia

Website:https://jurnal.umj.ac.id/index.php/penaliterasiEmail:penaliterasi@umj.ac.id

mengambil ponselnya

kembali, membaca lagi status

Rebecca. "Udah desperate

banget nih anak, dikiranya mati bisa dijadiin lelucon.

Gue komen ah."

"Banci lo kalau ikutan ngebully. Zaman sekarang jempol itu lebih tajam dari lidah, sesuatu yang lo kira lucu itu nyakitin hati orang lain," tukasnya lugas, dan Deni akhirnya terdiam, mengurungkan niatnya untuk ikutan berkomentar. (hlm. 60)

Kutipan tersebut terdapat gambaran Deni yang hendak menuliskan komentar hujatan untuk status Facebook Rebecca, namun ucapan Nathan membuatnya mengurungkan niat. Nathan berkata bahwa mereka yang melakukan perundungan pada Rebecca adalah banci. Dia juga berkata bahwa zaman sekarang jempol itu lebih cepat daripada lidah. Sesuatu yang temanteman Nathan tertawakan bisa saja menyebabkan luka yang menyakiti hati orang lain. Ujaran tersebut memperlihatkan dengan jelas bahwa Nathan bukanlah orang yang mudah menghakimi orang lain.

\section{Unsur Pikiran}

Pikiran adalah proses pengolahan stimulus yang berlangsung dalam domain representasi utama (Arifuddin, 2010). Pikiran dikondisikan oleh linguistik atau ilmu bahasa dan pengalaman yang diubah dalam wujud konsep kata yang telah tersedia. Proses berpikir meliputi rangkaian-rangakaian sebab akibat, menganalisisnya dari yang umum ke hal-hal yang khusus atau menganalisis dari hal-hal yang khusus ke hal-hal yang umum. Temuan ujaran tokoh protagonis di dalam novel Hello Salma karya Erisca Febriani dapat digambarkan dalam kutipan di bawah ini.

a. Salma menghela napas. "Nilaiku nggak cukup untuk kedokteran UI, belum mencapai passing grade. Kecil kemungkinan diterima. Gimana kalau aku pilih Sastra Indonesia aja, Ma?"

"Papa pasti nggak setuju. Kamu tahu kan gimana keras kepalanya Papa? Asti menatap Salma, "lagi pula, Mama yakin kamu pasti bisa."

Mungkin, kata-kata itu berniat menyemangati. Akan tetapi, bagi Salma, justru menambah beban baru untuknya karena ibunya sudah memberikan ekspektasi tinggi. (hlm. 116-117)

Kutipan di atas menjelaskan tentang Salma yang berkata pada ibunya bahwa nilainya tidak cukup untuk kedokteran. Pernyataan itu disanggah oleh ibunya. Ibunya terus memberi dorongan pada Salma dan meyakinkan kalau dia mampu. Namun, Salma tidak berpikir demikian. Semangat yang ibunya berikan itu justru terasa seperti beban baru. Ibunya terlalu memberikan ekspektasi yang tinggi. 
Fatimah ${ }^{1)}$, Ratna Dewi Kartikasari ${ }^{2)}$ : Karakter Tokoh Protagonis dalam Novel Hello Salma Karya EriscaA Febriani dan Implikasinya terhadap Pembelajaran Bahasa Indonesia

Website:https://jurnal.umj.ac.id/index.php/penaliterasiEmail:penaliterasi@umj.ac.id

b. "Kedokteran swasta kan mahal. Salma kayak orang yang kehilangan semangat. Gue ngerti perasaan dia. Dia pasti ngerasa beban banget, anak satu-satunya, harapan orang tuanya cuma ada di Salma, dan Salma pasti ngerasa udah ngecewain kedua orang tuanya." Rahma menghela napas perlahan.

Nathan tidak melanjutkan. Dia terkejut sekaligus bersalah karena tidak ada di sisi Salma selama gadis itu terpuruk. Lantas dikaitkan pertemuannya dengan Salma di komunitas Love Yourself, melihat Salma menangis di Kafe Teramochi-walau hanya sekadar menitikkan air mata, dan penampilan Salma yang terlihat lebih kurus. Nathan juga tahu, Salma bukan tipe orang yang pintar bercerita secara langsung, dia lebih memilih memendam semuanya sendirian. Memikulnya tanpa mau membagi ke orang-orang. Nathan takut Salma tenggelam dalam kesedihan. (hlm. 211)

Kutipan di atas menjelaskan tentang pertemuan Nathan dan Rahma. Rahma menjelaskan pada Nathan tentang kondisi Salma dan hal apa saja yang menimpanya. Nathan merasa terkejut. Dia pun mengaitkan pertemuannya dengan Salma di komunitas Love Yourself dan saat melihat Salma meneteskan air mata di Kafe Teramochi. Nathan teringat tentang Salma yang tidak pintar bercerita atau mengungkapkan perasaan. Saat itu juga, dia takut Salma akan tenggelam dalam kesedihan.

Implikasi terhadap pembelajaran bahasa Indonesia mengenai karakter protagonis tokoh dapat menjadi ilmu baru bagi peserta didik, membentuk karakter peserta didik yang baik, tangguh, memiliki jiwa kepemimpinan, dan menjadi pahlawan dalam cerita kehidupan mereka. Peserta didik dapat mengidentifikasi dan mengomentari bagian-bagian yang membangun dalam karya sastra, baik novel, cerpen, atau pun buku fiksi lainnya sehingga dapat mengembangkan kemampuan kognitif peserta didik.

Secara akademik, peserta didik dapat menganalisis, menyusun ulasan, mempresentasikan, dan memberikan tanggapan pada buku fiksi yang telah mereka baca.

\section{KESIMPULAN}

Berdasarkan hasil dan penafsiran data penelitian pada bab sebelumnya, penulis dapat menarik simpulan bahwa data hasil penelitian tersebut terdapat 204 kutipan yang ditampilkan tokoh Salma dan Nathan. Kedua tokoh tersebut memiliki karakter tokoh protagonis yang dominan pada aspek pikiran yang mencapai $39 \%$ dengan 80 kutipan. Aspek lainnya dilanjutkan dengan aspek tindakan mencapai 26\% dengan 52 kutipan dan aspek ujaran mencapai $35 \%$ dengan 72 kutipan. 
Fatimah ${ }^{1)}$, Ratna Dewi Kartikasari ${ }^{2)}$ : Karakter Tokoh Protagonis dalam Novel Hello Salma Karya EriscaA Febriani dan Implikasinya terhadap Pembelajaran Bahasa Indonesia

Website:https://jurnal.umj.ac.id/index.php/penaliterasiEmail:penaliterasi@umj.ac.id

Karakter tokoh protagonis novel Hello Salma memberikan nilai positif dalam menanam nilai-nilai kebaikan, seperti patuh pada orang tua, jujur kepada orang lain, berani berpendapat, dan membantu teman yang kesulitan. Sikap dan perilaku tokoh Salma dan Nathan dapat dijadikan teladan dalam kehidupan manusia dan dapat menjadi sarana dalam meningkatkan kemampuan apresiasi sastra bagi kehidupan sehari-hari melalui pemahaman struktur karakter setiap manusia.

Karakter protagonis yang melekat dalam diri tokoh Salma dan Nathan memiliki perasaan positif serta memberikan gambaran mengenai kehidupan yang penuh rintangan dan membutuhkan perjuangan. Cerita dalam novel ini menunjukkan bahwa berbagai rintangan hidup dapat dilewati sehingga manusia dapat mencapai tujuan atau impian mereka.

Analisis karakter protagonis pada penelitian ini memiliki implikasi yang baik. Implikasi terhadap pembelajaran bahasa Indonesia mengenai karakter protagonis tokoh dapat menjadi ilmu baru bagi peserta didik, membentuk karakter peserta didik yang baik, tangguh, memiliki jiwa kepemimpinan, dan menjadi pahlawan dalam cerita kehidupan mereka. Pendidik dapat menjelaskan kepada peserta didik melalui pembahasan materi mengenai sastra dengan memahami karakter tokoh protagonis yang mungkin belum diketahui oleh peserta didik. Peserta didik dapat mengidentifikasi dan mengomentari bagian-bagian yang membangun dalam karya sastra, baik novel, cerpen, atau pun buku fiksi lainnya sehingga dapat mengembangkan kemampuan kognitif peserta didik. Secara akademik, peserta didik dapat menganalisis, menyusun ulasan, mempresentasikan, dan memberikan tanggapan pada buku fiksi yang telah mereka baca.

Novel Hello Salma karya Erisca Febriani dapat dijadikan sebagai bahan ajar yang aktual dan menarik dalam pembelajaran bahasa Indonesia serta dapat menumbuhkan minat baca peserta didik. Dengan menggunakan bahan ajar yang menarik, pendidik dapat menilai tanggung jawab, rasa ingin tahu, cara berpikir peserta didik, serta perkembangan kognitif peserta didik dalam menganalisis suatu soal.

Berdasarkan hasil simpulan di atas, penulis merasa perlu untuk mengajukan beberapa saran. Adapun saran-saran yang penulis ajukan sebagai berikut:

1. Penulis dapat menjadikan penelitian ini sebagai acuan untuk melatih daya pikir sehubungan dengan karakter tokoh protagonis dalam novel ini lebih baik dan lebih mendalam.

2. Bagi pembaca, karya sastra seperti novel Hello Salma diharapkan dapat menambah 
Fatimah ${ }^{1)}$, Ratna Dewi Kartikasari ${ }^{2)}$ : Karakter Tokoh Protagonis dalam Novel Hello Salma Karya EriscaA Febriani dan Implikasinya terhadap Pembelajaran Bahasa Indonesia

Website:https://jurnal.umj.ac.id/index.php/penaliterasiEmail:penaliterasi@umj.ac.id

wawasan tentang karakter agar masyarakat luas juga dapat memahami lebih mendalam mengenai karakter protagonis dalam diri manusia.

3. Guru bahasa Indonesia disarankan menekan arti pentingnya karakter sebagai alat untuk menanamkan nilai kejiwaan pada peserta didik dan menjadikannya sebagai sarana dalam memahami unsur ekstrinsik dan intrinsik di dalam karya sastra.

4. Mahasiswa atau pelajar hendaknya tidaklah menganggap bahwa karya sastra seperti novel hanya karangan belaka yang bersifat imajinatif, namun harus dipahami bahwa karya sastra novel mengandung unsur cerminan masyarakat dan nilainilai yang terkandung sehingga menarik dan berguna untuk diri sendiri.

\section{REFERENSI}

Arifuddin.

(2010).

Neuropsikolinguistik.Jakarta : Rajawali Press.

Bahtiar, A. dan Aswinarko. (2013). Metode Penelitian. Tangerang: Pustaka Mandiri.

Febriani, E. (2018). Hello Salma. Depok: Coconut Book.

Kridalaksana, H. (2011). Kamus Linguistik (Edisi Keempat). Jakarta: Gramedia Pustaka Utama.

Sugiono. (2017). Metode Penelitian Kuantitatif, Kualitatif, dan $R \& D$. Bandung: Alfabeta.

Wardiah, M. L. (2016). Teori Perilaku dan Budaya Organisasi. Bandung: Pustaka Setia.

Wardiah, M. L. (2016). Teori Perilaku dan Budaya Organisasi. Bandung: Pustaka Setia. 